https://doi.org/10.5719/aub-g/69.1/6

\title{
THE MEANING AND WAY OF PRESENT OF THE BIO-METEOROLOGICAL INFORMATION AND COMPONENT IN THE WEATHER PROGNOSES
}

\author{
ELENA GRIGORE ${ }^{1}$, DANA MARIA CONSTANTIN (OPREA) ${ }^{1}$, \\ ELENA BOGAN ${ }^{2}$, FLORINA TATU ${ }^{3}$
}

\begin{abstract}
In order to ensure human security, it is useful both conducting the assessments and presenting the information of the biometeorological component in the weather prognoses specific to the public and/or private communication channels. Among the essential requirements for the specific functioning of the Member States of the European Union (EU), such information is needed in the preparation of the perception and responsible positions regarding the risks of the weather and the climate on human health. The present study aims to be a synthesis obtained through a comparative approach by which the importance of coherent, organized and systematic transmission of the information through the weather forecasts is highlighted and emphasized. The provision of this information, regardless the country must respect the current legislation and the ISO 7730 and must take into account the potential of a bio-meteorological risk and provide the specific identification and reporting regime.

Keywords: biometeorology, information, prognosis, graphic and cartographic representation, legislation.
\end{abstract}

\section{Introduction}

In a human society, in order to ensure the human safety, the protection and health of its members, it is useful to present both the biometeorological

1 University of Bucharest, Faculty of Geography, Depart. of Meteorology-Hydrology, ela_zigzag@hotmail.com, danamartines@yahoo.com

2 University of Bucharest, Faculty of Geography, Depart. of Human and Economic Geography, elena.bogan@yahoo.com

3 University of Bucharest, Faculty of Geography, Depart. of Geomorphology, Pedology and Geomatics, foleaf@yahoo.com 
information and component in the weather prognoses regardless the type of the environment, through which the transmission is made (public or private). This paper aims to understand both the way in which the bio-meteorological information programs have been implemented and the different ways of warning the population, at local and European level. The study is a comparative analysis of several EU Member States' communication media. In general, the methods of communication differ from state to state due to the databases of data used, the analyzed indicators, but also due the spatial analysis scale (national, regional, local). Thus, often the comparison of the evaluation results may seem a difficult process, but the standardization of methodologies makes this act easier.

The bio-meteorological analysis, from the perspective of the main risk factors (Grecu 2016) that can affect the human health, concerns the complexity of the direct and indirect relational system between the geophysical / geochemical environment and the environment specific to the living organisms, plants, animals and humans, because the effect, either conjugated or separately, determines the human body to have a regulatory mechanism and a physiological adaptation so that it may remain functional (McMichael et al. 2003).

Bio-meteorology makes possible to highlight, through a series of quantitative information referring to the meteorological conditions, the influence of the rapid variations of the meteorological elements on the human body. Over a lifetime, our organism is subject to more environmental conditions (Grecu 2016), being affected by its qualities, directly or indirectly, with a number of positive or harmful effects on the human health. The quantitative information highlighting the influence information of the meteorological conditions has been subject to attention for both the international and national studies, such as: Beçancenot 1974; Mieczkowski 1985; Kyle 1992; etc. and Ionac 2008; Apostol 2011; Grigore 2011; Croitoru 2012; Teodoreanu 2013; etc. each author presenting a series of aspects useful in the process of evaluating and highlighting an optimal or ideal condition in which a human organism can function normally without affecting the daily activity. 


\section{Methodology}

The present study aims to be a synthesis of the way the bio-meteorological information is transmitted to the large public. The bio-meteorological information and component should be given a unitary presentation, be easy to understand by the general public. Firstly, this process involves an adequate graphic and cartographic representation (Cotet, Nedelcu 1976).

Then, the provision of information, regardless the country, must respect the current legislation and the ISO 7730 (made by the British Standard BS EN), must take into account the potential of the bio-meteorological risk and must foresee the specific identification and reporting regime, because the bio-meteorological information is generally used for the purpose of preventing and protecting the population to whom it is addressed.

In order to accomplish this study, the data collection process has required the consultation of a vast virtual bibliography. The meteorological services or national or a of the higher education institutions, the massmedia channels, besides the meteorological information, also develops the bio-meteorological databases. These statistical databases highlight both the way of defining the bioclimatic indices, the specific terms, the limits of applicability and the value thresholds of the indices presented, depending on the type of bioclimate, as well as the specific methodology for the graphic and cartographic representations used by each weather service separately.

Thus, in the weather prognosis, the streamlining of both data and the useful information transmission to the population is aimed and also the way the transmitted message is received, how it was perceived and assimilated.

\section{Results and discussions}

Because of the weather instability, of the daily and seasonal variability of the meteorological and climatic factors (such as: air temperature, relative air humidity, wind, solar radiation intensity etc.), the bio-meteorological-climatic factors are viewed and presented as evaluation indicators of the different negative or positive effects from a 
certain environment. For example, analysing how the sites are made, one can see that these are also accompanied by the information on a number of factors that strongly influence the environment and have a constant impact on the health and human performance.

The presentation of the climatic factors is an extremely important process, because their continuous spatial and temporal variation requires a permanent adaptation of all the physiological systems of integration and control of the human body. Therefore, the human comfort is directly dependent on the weather and local climatic conditions, which can diminish or enhance the vital human capacity. Taking into account these, such type of analysis is very useful irrespective the region and country and is generally useful in the systematic approaches of the environmental health.

An important step in evaluating how the bio-meteorological information is presented in the programs which aim providing the daily weather prognoses is the identification and analysis of the products offered by different meteorological services producing bio-meteorological reports (Table 1).

The analysis should also capture how the bio-meteorological-climatic indexes used in reports, effectively express the discomfort or the thermic comfort, the most frequent being the UV Index, UTCI, the Temperature-Humidity Index, the Effective Temperature and the Wind-Chill and how the population has received, understood and appreciated the product and its impact, the result being visible in the attitude by which the protective measures against various weather conditions are taken (Table 2).

The bio-meteorological information and component should be given a unitary presentation and be easy to understand by the general public, using an adequate graphic and cartographic representation. The most commonly used are the graphics and thematic maps by regions, but also by manifestation intervals and synoptic tables. 
THE MEANING AND WAY OF PRESENT OF THE BIO-METEOROLOGICAL INFORMATION

Meteorological services with frequent bio-meteorological reporting in mass media

\begin{tabular}{|c|c|c|}
\hline $\begin{array}{c}\text { the type of } \\
\text { service }\end{array}$ & name & Webpage name \\
\hline \multirow{4}{*}{$\begin{array}{l}\text { research centers } \\
\text { and bio- } \\
\text { meteorological } \\
\text { research } \\
\text { institutes }\end{array}$} & BIOMETEOLAB & www.naturmed.unimi.it \\
\hline & Consiglio Nazionale delle Richerche & www.ibimet.it \\
\hline & METEOSALUTE & www.biometeo.it \\
\hline & $\begin{array}{c}\text { Centro Interdipartimentale } \\
\text { di Bioclimatologia Università degli } \\
\text { Studi di Firenze etc. }\end{array}$ & www.dispaa.unifi.it \\
\hline \multirow{8}{*}{$\begin{array}{l}\text { offices, national } \\
\text { services and } \\
\text { weather offices }\end{array}$} & $\begin{array}{l}\text { National Weather Service-National } \\
\text { Oceanic and Atmospheric Administration }\end{array}$ & www.weather.gov \\
\hline & $\begin{array}{c}\text { Deutscher Wetterdienst - Wetter } \\
\text { und Klima au seiner Hand }\end{array}$ & www.dwd.de \\
\hline & $\begin{array}{l}\text { Met Office - National Meteorological } \\
\text { Office of the United Kingdom of Great } \\
\text { Britain and Northern Ireland }\end{array}$ & www.metoffice.gov.uk \\
\hline & $\begin{array}{c}\text { Hydrometeorological Service } \\
\text { of the Republic of Serbia }\end{array}$ & www.hidmet.gov.rs \\
\hline & Servicio Meteorologico National & www.smn.gov.ar \\
\hline & $\begin{array}{c}\text { Australian Government - Bureau } \\
\text { of Meteoroloy }\end{array}$ & www.bom.gov.au \\
\hline & $\begin{array}{l}\text { National Oceanic and Atmospheric } \\
\text { Administration }\end{array}$ & www.noaa.gov \\
\hline & $\begin{array}{c}\text { National Meteorological } \\
\text { Administration etc. }\end{array}$ & www.meteoromania.ro \\
\hline \multirow{5}{*}{$\begin{array}{l}\text { structures } \\
\text { specialized in } \\
\text { presenting } \\
\text { weather news }\end{array}$} & www.ilmeteo.it & \\
\hline & meteonews.ch & \\
\hline & www.meteo17angliers.fr & \\
\hline & www.wetter.com & \\
\hline & www.theweathernetwork.com etc. & \\
\hline
\end{tabular}


The main bio-meteorological/bio-climatic sites and indices used in the weather prognoses

\begin{tabular}{|c|c|}
\hline Webpage name & The presented index \\
\hline www.naturmed.unimi.it/meteolab.html & $\begin{array}{l}\text { UVI, ISH, ISE, HUMIDEX, RSI, } \\
\text { SSI, TEE, THI, Pr-WIND-CHILL, } \\
\text { DI THOM, HI }\end{array}$ \\
\hline http://www.metoffice.gov.uk & UVI, PET \\
\hline http://www.dwd.de/ & UVI, PET \\
\hline http://www.erh.noaa.gov/iln/tables.htm & HI, Pr-WIND-CHILL \\
\hline http://www.weather.com/maps/ & HI, Pr-WIND-CHILL \\
\hline $\begin{array}{c}\text { http://www.bom.gov.au/; } \\
\text { http://www.weather.gov/ } \\
\text { http://www.wetterkontor.de/de/ueberuns.asp } \\
\text { www.hidmet.gov.rs; www.smn.gov.ar } \\
\text { www.meteo17angliers.fr; www.ilmeteo.it; } \\
\text { www.meteo.gr } \\
\text { http://www.theweathernetwork.com } \\
\text { http://www.bbc.co.uk/weather/ }\end{array}$ & UVI \\
\hline $\begin{array}{c}\text { www.tv5.org } \\
\text { http://www.metservice.com/national } \\
\text { www.ilmeteo.it }\end{array}$ & PET \\
\hline $\begin{array}{c}\text { http://www.meteolafleche.com/temperature.html } \\
\text { \#humidex }\end{array}$ & HUMIDEX \\
\hline http://www.summersimmer.com/home.htm & SSI \\
\hline
\end{tabular}

Some of the bio-meteorological articles offered to the general public for information are presented through the photographic collage (Photo 1) which is intended to be a qualitative and quantitative synthetic expression of the main graphic and cartographic forms agreed by various meteorological services in order to provide the bio-meteorological information to the general public.

If the variability of environmental factors is evidenced by a freedom of expression, at the level of a human society, this variation requires the implementation of a specific security process. Thus, the presentation of information respects a number of geographical principles, such as: the spatial distribution, division, scaling, structure, correlation, causality etc. Also, the same presentation of the biometeorological information must comply and the analysis models (like those based on: 
generalization and precision (analytical or mathematical); physical characteristics (simulation at different scales); statistical - mathematics and visualization (graphic transposition and raffle cartography etc.).

Where the chronology and dynamics are supported by the coding mechanism of the exposed elements and by the mapping on samples (in order to generate interpolated data) with a simple exposure as the indicators develop complex relational systems.

The photographic collage (Photo 1) highlights the fact that the most services prefer maps with different graphic signs - rectangles and triangles of the values corresponding to the different meteorological stations in the analysed space (Photo 1a), dialog boxes - a linking element through the existence of a link which gives a detailed picture of the given index, the isolines (Photo 1b), the numeric notation (Photo 1a) etc., all respecting the limits and the applicability intervals specific to the bio-meteorological indexes, followed by the synoptic tables of synthesis (Photo 1c), the explanatory schemes, the evolution charts (Photo 1d), the explanatory theoretical syntheses (Photo 1e) etc. Regardless the way of presentation, one can found that the information that generates quantitative data can be identified, analysed and interpreted, allowing to detect the differences from a normal state or the expected values and to sustain the decisions underlying the accomplishment of the prognosis or the management strategies on the security of a human society.

The information mechanisms are also supported by the legal framework that comes with the aim of standardizing and streamlining the various ways of transmitting, first of all, of the warning messages about the weather and climatic conditions that may affect the health of the population. The transmission of messages in a simple and conclusive form was possible both through the methodology of standardizing the bio-meteorological indicators and by homogenizing the ways of evaluation and presentation, actively participating in educating the public, in the sense of assimilation of the main risk concepts. 


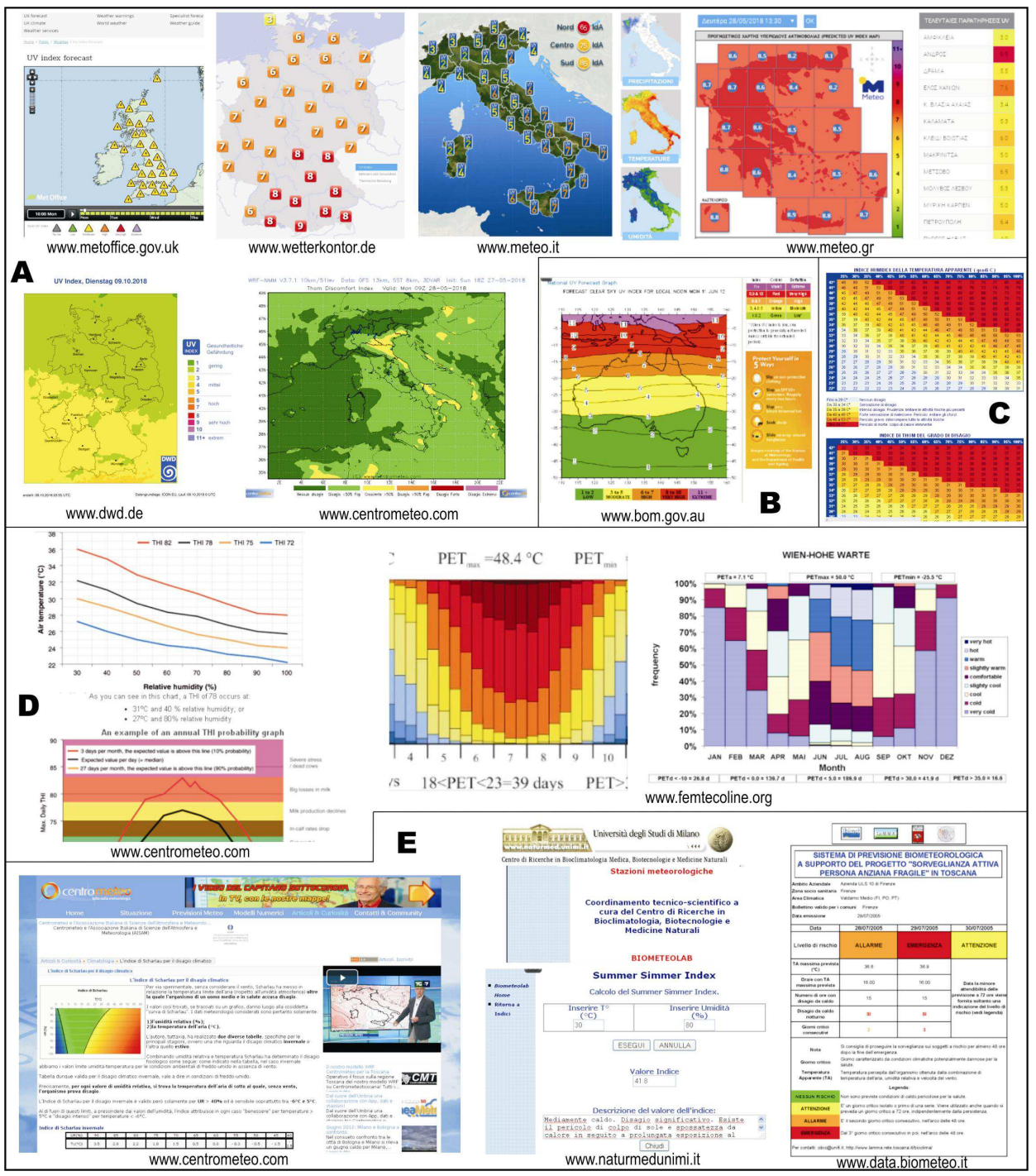

Photo 1. The main ways of graphic and cartographic representation of the bio-meteorological information through different media channels

Thus, the legal basis has a specific purpose, namely to fix: the specific elements, periods and conditions; the bio-meteorological and bio-climatic risk reporting authority; implementing a unitary system of evaluation and presentation of their values, broadening the audience and promoting safe preventive behaviours. 
For example, the most widely used guide is the one launched by WHO - the Global Solar UV Index Practical Guide, in 2002, where the protection measures are presented according to the exposure categories and the UV index values (Tab. nr. 3).

Table 3

The main protective measures based on the UV index values

\begin{tabular}{|c|c|c|}
\hline $\begin{array}{c}\text { Value } \\
\text { of the index }\end{array}$ & $\begin{array}{l}\text { Category } \\
\text { of exposure }\end{array}$ & Protection measure \\
\hline$<2$ & small & no protection \\
\hline $2.1-5$ & moderate & \multirow{2}{*}{ hide, cover, protection of the eyes } \\
\hline $5,1-7$ & high & \\
\hline $7,1-10$ & $\begin{array}{l}\text { very high } \\
\text { extreme }\end{array}$ & $\begin{array}{l}\text { maximal protection of the eyes and body and avoid } \\
\text { the exposure during midday }\end{array}$ \\
\hline
\end{tabular}

These bio-meteorological reports should be regarded as warning systems, leaving aside the desire for audience of those who transmit the news, ways in which both the comfort index and the thermic discomfort can be identified, as well as the weather conditions associated with the adverse effects on health. Also, this complex relational system implies that the weather prognosis process is made accurately, because the positive or negative results can be framed as prevented missed opportunities and the final and visible effect marks the loss of the population's confidence in this the type of prognosis, firstly, by misunderstanding of the meaning and utility.

In order to correlate the risk assessment modalities with their reporting formalities, there are a number of integrated public health protection policies (already applied in over 30 countries) actively supported by the World Meteorological Organization (WMO), the World Health Organization (WHO), which cooperate with the United Nations Environment Program (UNEP), the International Commission on Non-Ionizing Radiation Protection (ICNIRP), the German Federal Office for Radiation Protection (Bundesamt für Strahlenschutz) etc. The process of knowledge assimilation can be reduced to an initial stage, namely that through which the relevant meteorological and medical information is introduced in specific periodicals to the general public, 
then, the next stage is possible by the gradual recognition of information by the receiver, in the present case by the population and by the adaptation of its behaviour, which requires a change of conception on the multidisciplinary character of the weather reports in order to accept the next events.

\section{Conclusions}

So far, no bio-meteorological study has had a comparative character, knowing that the comparative studies are beneficial to human society, not only for the development of scientific knowledge, but also for improving the standard of living. In the last years, a lot of attention is paid to all the potentially harmful influences on the human beings, and through these bio-meteorological analyzes presented daily through the media channels, there can be evaluated the effective perception of the human body. Nowadays, the bio-meteorological or bioclimatic indicators are used as tools for assessing the positive or negative potential of the weather and climate, and the mode of transmission is seen as a means of raising public awareness of the possible risks of weather and climate.

From of the hazardous factors that can influence human health, biometeorological ones are the most aggressive because of their continuous variation in space and time. That is why the detailed analysis of such bioclimatic indices is useful on a unique scale of reference to best describe the people's weather or climate-related physiological comfort or risks, because human health is directly connected to the climatic or microclimatic comfort.

All alert models are for the purpose of taking protective measures and assessing the effect they have on the human health. This is possible due to the fact that more attention has been paid to all the potentially harmful influences. Through these analyzes presented daily through the media channels, the effective perception of the human body can be assessed, because the analyzed indices have high amplitudes of variation, which impose the human organism at different physiological demands of adaptation and control. Generally, any kind of information campaign of the population is meant to be a success, and so that this 
success may be real, the information must target both educating the people by acquiring attitudes and preventive behaviours and providing programs which promote the behaviour values in society.

For these reasons, the elaborated prognoses must be interdisciplinary, respectively accessible to the newspapers, radio, television, which are the main means of dissemination of the bio-meteorological information, as well as to the media for the tourist activities - hotels, travel agencies etc., and the message should be transmitted precisely, briefly, clearly and adapted to the specificity of the activity. The prognoses, regardless of the final presentation mode, should help the most exposed and vulnerable categories of the population - children, the elderly and tourists, by informing them of the possible harmful effects caused by the atmospheric and climatic factors and the maximum risk periods.

The present study aimed to obtain a suggestive and synthetic image of the ways of highlighting the bio-meteorological information presentation formulas, possibly by analysing the graphic and cartographic presentation formula, the number of hits and comments accompanying the specialized sites, as well as by the way in which different states of discomfort or bioclimatic comfort of the human body are perceived in certain climatic conditions that have been expressed quantitatively through the bioclimatic indices, even if this is a subjective perception. The photographic collage highlights, even on a simple evaluation, that the ISO standards are respected and applied appropriately, regardless the form of expression that may be more or less attractive due to the desire to enhance the audience.

It is also underlined that any system of health and safety control of the society can be integrated into the resource management as it involves the operator training and the resulting relational system can be used effectively throughout the world.

\section{Acknowledgements}

The authors would like to give thanks to the anonymous reviewers. All authors contributed equally to this article. 


\section{BIBLIOGRAPHICAL REFERENCES}

Apostol, L., Gaceu, O., 2011, 'The climatic-touristic potential of the Romanian Black Sea Coast during summer established according to the method of Besancenot, Mounier and de Lavenne'. Carpathian Journal of Earth and Environmental Sciences, vol. 6 , no. 1 .

Beçancenot, J.P., 1974, 'Premieres donnes sur les stress bioclimatiques moyens en France'. Annales de geographie, vol. 83(459), pp. 497-530.

Coteț, P.V., Nedelcu, E., 1976, Principii, metode şi tehnici moderne de lucru în geografie, Bucureşti, Editura Didactică şi Pedagogică.

Croitoru, A.E., Sorocovschi, V., 2012, Introducere in biometeorologia umană, Cluj-Napoca, Casa Cărții de Ştiință.

Grecu, F., 2016, Hazarde şi riscuri naturale, Bucureşti, Editura Universitară.

Grigore, E., 2011, Potențialul bioclimatic al Podişlui Dobrogei de Sud - Teză de doctorat susținută public, Universitatea din Bucureşti.

Hill, A.B., 1965, 'The Environment and Disease: association or causation?, in Proceedings of the Royal Society of Medicine, vol. 58, pp. 295-300.

Ionac, N. , Ciulache, S., 2008, Atlasul bioclimatic al României. Bucharest: Ars Docendi.

Kyle, W.J., 1992, 'Summer and winter patterns of human thermal stress in Hong Kong' in: Kyle W.J. and Chang C.P. (eds.). Proc. of the 2 nd Int. Conference on East Asia and Western Pacific Meteorology and Climate, Hong Kong. World Scientific, Hong Kong, pp. 557-583.

Mieczkowski, Z., 1985, The tourism climatic index: a method of evaluating world climates for tourism, The Canadian Geographer https://doi.org/10.1111/j.1541-0064.1985.tb00365.x

McMichael, A.J., 2003, Climate change and human health, Geneva, World Health Organization Parsons, K., 2003, Human Thermal Environments, 2nd ed., London, Taylor and Francis.

Teodoreanu, E., 2002, Bioclimatologie umană, Bucureşti, Editura Academiei Române.

** 2000, BS 7963, 'Ergonomics of the thermal environment-Guide to the assessment of heat strain in workers wearing personal protective equipment', BSI, London.

*** 2002, WHO - 'Global Solar UV Index Practical Guide', Switzerland.

***2005, ISO 7730, 'Ergonomics of the thermal environment - Analytical determination and interpretation of thermal comfort using calculation of the PMV and PPD indices and local thermal confort criteria', Geneva: International Standards Organisation.

** 2018, IPCC, 'Global warming of $1.5^{\circ} \mathrm{C}$ '. An IPCC Special Report on the impacts of global warming of $1.5^{\circ} \mathrm{C}$ above pre-industrial levels and related global greenhouse gas emisson pathways, in the context of strengthening the global response to the threat of climate change, sustainable development, and efforts to eradicate poverty, https://www.ipcc.ch/pdf/special-reports/sr15/sr15_draft.pdf

www.naturmed.unimi.it

www.biometeo.it

www.dispaa.unifi.it

www.weather.gov

www.dwd.de

www.metoffice.gov.uk 
THE MEANING AND WAY OF PRESENT OF THE BIO-METEOROLOGICAL INFORMATION AND COMPONENT IN THE WEATHER PROGNOSES

www.hidmet.gov.rs

www.smn.gov.ar

www.bom.gov.au

www.noaa.gov

www.meteoromania.ro

www.ilmeteo.it

www.meteonews.ch

www.meteo17angliers.fr

www.wetter.com

www.theweathernetwork.com 
